\title{
Tuzlu ve Jipsli Sahalarda Oyuntu İçinde Doğal Yetişen Ağaç ve Çalı Türleri: Ballıca Deresi Havzası
}

\author{
Ebru ÇERÇ $\dot{I}^{1}$, Ceyhun GÖL ${ }^{1 *}$ \\ ${ }^{1}$ Çankırı Karatekin Üniversitesi, Orman Fakültesi, Orman Mühendisliği Bölümü, 18200, Çankırı
}

\section{Öz}

Bu araştırmanın amacı; Çankırı-Ballıca Deresi Havzası tuzlu ve jipsli sahalarında oyuntu içi doğal ağaç ve çalı türlerinin gelişimini incelemektir. Araştırma, doğu, batı ve kuzey bakılarda belirlenmiş on sekiz adet oyuntuda yürütülmüştür. Oyuntuların bazı morfolojik özellikleri ve odunsu türler incelemeye konu edilmiştir. Oyuntularda çalı türleri daha geniş yayılış göstermiştir. Kuzey ve doğu bakılara özgü yayılış gösteren türlerin olduğu, batı bakıda ise tüm alanda görülen türlerin bulunduğu tespit edilmiştir. Oyuntularda eğimin azaldığı mansap bölgesinde ağaç, daha yüksek eğimli memba bölgesinde çalı türleri yayılış göstermiştir. Oyuntularda eğim yükseldikçe, bitki gelişimi gerilemiştir. Eğimin düştüğü oyuntu orta bölgesinde bitkiler yoğunlaşmıştır. Bu araştırma, oyuntu ıslah çalışmalarında, oyuntu karakteristikleri ve iklime uygun yerel çalı türlerinin kullanılması gerektiğini ortaya koymuştur.

Anahtar Kelimeler: Oyuntu, erozyon, çölleşme, ıslah, havza, Çankırı.

\section{Naturally Growing Tree and Brush Species in Gully in Salty and Gypsum Areas: Ballıca Stream Watershed}

\begin{abstract}
The objective of this study was to examine the development of natural tree and shrub species in the gully in the salty and gypsum areas of the Çankırı-Ballıca stream watershed. The research was carried out in eighteen gullies determined on the East, West and North sides. Some of the morphological features of the gullies and woody species naturally grown in and around the gully were studied. Shrub types were more widely distributed in the gullies. It has been determined that there are species that are specific to the north and east aspects, and that there are species that can be seen in the whole area in the west side. In the downstream region where the slope is decreased in the gully, the tree species have spread in the higher slope upstream region. As the slope increased on the gully the plant growth is decreasing. Plants are concentrated in the middle of the gully where the slope decreases. This research revealed that gully characteristics and local shrub species suitable for the climate should be used in the selection of plant species in gully breeding studies.
\end{abstract}

Keywords: Gully, erosion, desertification, improvement, watershed, Çankırı. 


\section{Giriş}

Karasal ekosistemlerin temel ögesi topraktır. Buna karşın, aşırı ve yanlış arazi kullanımı, bitki örtüsünün tahribi, yangınlar, aşırı otlatma gibi nedenlerle toprak verimliliğinin azalması, arazi bozulumuna neden olmaktadır (Celilov ve Dengiz, 2019). Dünya'da erozyonla yaşanan toprak kaybı, sonunda çölleşmeye neden olmaktadır. Türkiye, tüm dünyada toprakları en fazla erozyona uğrayan ülkeler arasındadır (Babalık, 1999; Oruç, 2010; Karagöz ve ark., 2017).

Erozyon, yer küre üzerindeki toprak ve çeşitli yüzey maddelerinin eğim boyunca taşınmasıdır (Sarı, 2000). Erozyon nedeniyle, toprağın verimliliği kaybolmakta, zamanla toprak ve su kaynakları zarar görmektedir (Khoshoo ve Tejwani, 1993). Doğal erozyon oluşum sürecini; topoğrafya, iklim, toprak ve bitki örtüsü belirlemektedir (Doğan, 2011; Kaş, 2016). Ancak, antropojenik etkiler bu sürecin hızlanmasına ve zararın artmasina neden olmaktadir.

Dünya'da kurak ve yarı kurak alanlar erozyonla arazi bozulumunun en yüksek olduğu bölgelerdir (Şengönül ve Özçelik, 2014). Türkiye'nin kurak ve yarı kurak iklimi içerisinde bulunan İç Anadolu Bölgesi, bitki örtüsü bakımından en fakir ve aynı zamanda en kurak bölgesidir (Çetik, 1985; Atalay, 2011). Bu nedenle İç Anadolu aynı zamanda en şiddetli erozyon yaşanan bölgedir. Kuraklık bitki gelişimini doğrudan etkileyen faktördür (Özkan, 2011). Bu nedenle kurak bölgeler, bitki örtüsü bakımından zayıf ve yetersizdir. Bitki örtüsü bakımından hassas olan bu ekosistemler erozyona karşı çok daha duyarlıdır. Kurak ve yarı kurak alanlarda yapılacak erozyonla mücadele çalışmalarının başarısında yetişme ortamı analizi, bitki tür seçimi, arazi hazırlığı ve bitkilendirme konuları büyük önem taşımaktadır (Zoralioğlu, 2006; Kırdar ve ark., 2011; ÇEM, 2017). Kurak sahaların ıslahında yapılacak en küçük yanlış değerlendirme veya uygulama çalışmalarının başarısızlıkla sonuçlanmasına yol açmaktadır (Şengönül ve Özçelik, 2014). Bu sahalarda mümkün olduğunca araziyi bozmayacak ve mevcut doğal bitki örtüsünü geliştirecek çalışmalar yapılmalıdır. Özellikle yamaçlarda toprak tahribatını en üst düzeye çıkaran oyuntu erozyon sahalarında toprak koruma çalışması yürütmek oldukça güçtür. Oyuntu erozyonunun oluşum sürecinde topoğrafik yapı, ana kaya, toprak özellikleri ve bitki örtüsü en önemli etkenlerdir. Oyuntu erozyonu, ekosistem bozulmasının en önemli göstergesidir (Gomide ve ark., 2014). Oyuntu erozyonu sahalarının ıslahı yüksek maliyet, iş gücü ve dikkat istemektedir. Bu nedenle oyuntu erozyonu ile mücadelede oluşum nedenleri, alınması gerekli toprak koruma önlemleri ve yetiştirilecek en uygun bitki türleri doğru belirlenmelidir. Oyuntu içi ve çevresinde erozyon önleyici bitki türü seçiminde yöreye uyum sağlamış (Atalay, 2011; ÇEM, 2017), adaptasyon yeteneği yüksek (Loschi ve ark., 2010) türler tercih edilmelidir (Gomide, ve ark., 2011). Oyuntuların sayısı ve uzunluğu üzerinde yağış, oluşan kanalların karakteristikleri üzerinde ise toprak ve bitki örtüsü etkilidir (Capra ve Scicolone, 2002).

Araştırmanın yürütüldüğü alan kuraklık, tuzluluk, jips, taşlılık, yüksek eğim ve sığ toprak gibi kötü ekolojik özelliklere sahiptir. Aynı zamanda yanlış tarım, aşırı ve yanlış otlatma, bitki örtüsünün tahrip edilmesi gibi antropojenik etkilerin de eklenmesi ile şiddetli erozyon yaşanmaktadır. Geçmişte alanda ağaçlandırma ve erozyon kontrol çalışmaları yürütülmüş olmasına rağmen yeterli başarı sağlanamamıştır. Araştırma ile oyuntu içi ve çevresinde doğal olarak gelişmiş ağaç ve çalı topluluklarının özellikleri ile oyuntu erozyonunu önlemedeki etkileri araştırılmış, ıslah çalışmalarında kullanılabilme olanakları incelenmiştir.

\section{Materyal ve Metot}

\subsection{Araştırma alanının tanıtımı}

Araştırma alanı, Çankırı il sınırları içinde, il merkezi güneyinde Eldivan İlçesi sınırları içerisinde bulunmaktadır. Araştırma alanı yüzölçümü 702,6 ha' dır. Araştırma alanı Çankırı - Eldivan karayoluna paralel uzanmakta olup Aşağıyanlar ve Yukarıyanlar köyleri arasında bulunmaktadır. Coğrafi bakımdan UTM; 542932 - 550193 doğu boylamları ile UTM; 4491833 - 4488572 kuzey enlemleri arasında yer almaktadır (Şekil 1). Araştırma alanı tepe ve tepeciklerden oluşan engebeli orta dağlık bir yapıya sahiptir (Şekil 2). 


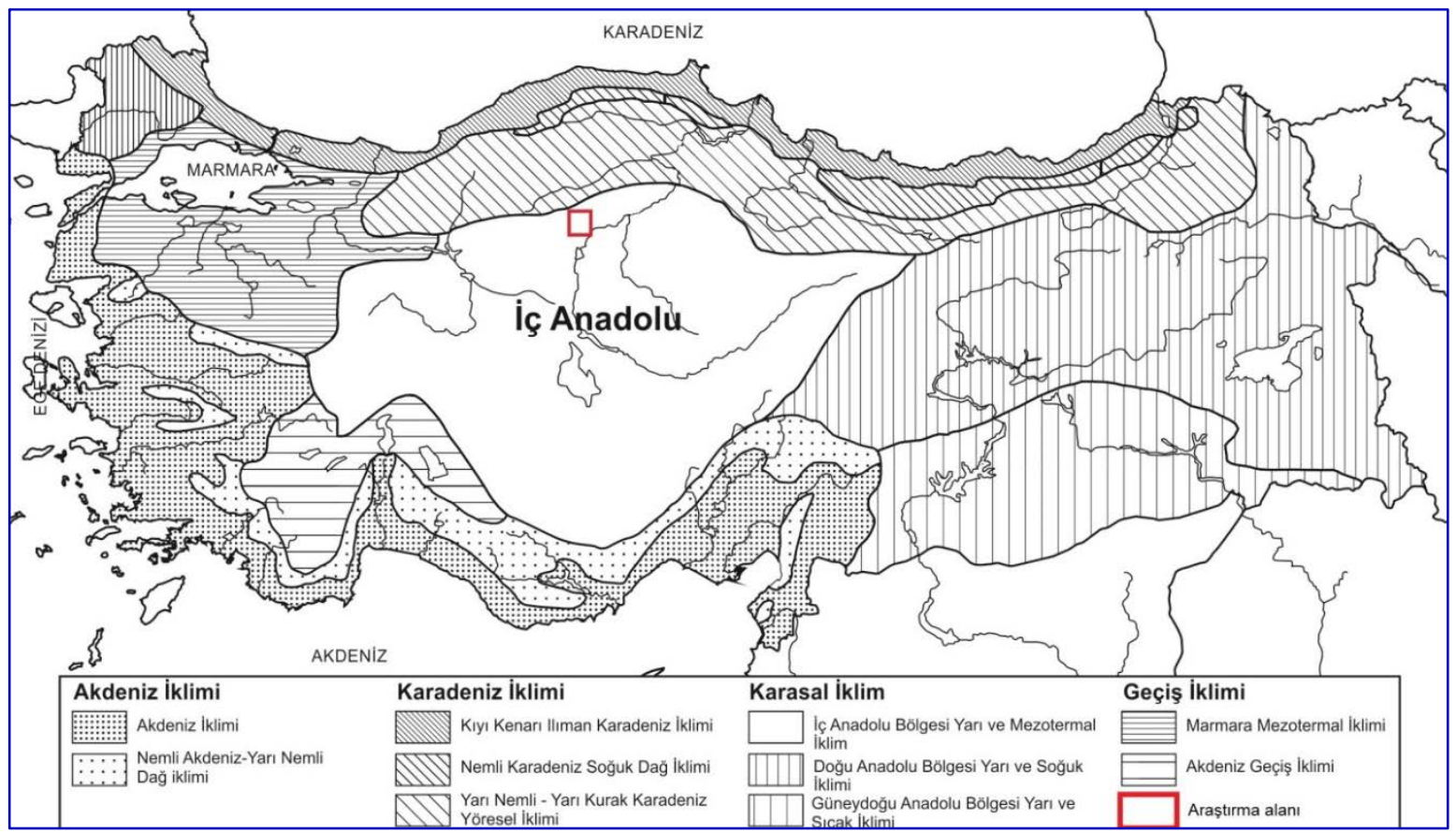

Şekil 1. Türkiye ekolojik bölgeleri haritası ve araştırma alanı (Atalay, 2014).

Araştırma alanının içinde yer aldığı Ballıca Havzası orta dağlık, düz ve taban arazilerden oluşmaktadır. Havzanın yükseltisi 686-1805 m arasında değişim göstermektedir. Ballıca Deresi Havzasının ortalama eğimi \%23’tür. Araştırma alanının ortalama yüksekliği 920 m, ortalama eğimi \%31,9, en yüksek noktası $1130 \mathrm{~m}$, en düşük noktası ise 729 m’dir. Araştırma alanının \%74,56's1 800-1100 m yükseltiler arasındadır (Tablo 1; Şekil 2). Araştırma alanının \%85,03’ ü çok eğimli - pek sarp eğim sınıfları grubu içerisinde yer almaktadır. Bu özelliği ile oyuntu erozyonu oluşturma potansiyeli yüksektir (Tablo 2; Şekil 3). Araştırma alanının \%90,97’si kuzey, doğu ve batı bakılardan oluşmaktadır.

Tablo 1. Araştırma alanı yükseklik dağılımı.

\begin{tabular}{|c|c|c|}
\hline \multirow{2}{*}{$\begin{array}{l}\text { Yükseklik } \\
\text { (m) }\end{array}$} & \multicolumn{2}{|c|}{ Araştırma Alanı } \\
\hline & $\begin{array}{l}\text { Alan } \\
\text { (ha) }\end{array}$ & $\begin{array}{l}\text { Alan } \\
(\%)\end{array}$ \\
\hline $729-800$ & 102,19 & 14,54 \\
\hline $800-900$ & 175,13 & 24,94 \\
\hline $900-1.000$ & 193,67 & 27,56 \\
\hline $1000-1100$ & 155,04 & 22,06 \\
\hline $1100-1200$ & 76,57 & 10,90 \\
\hline Toplam & 702,6 & 100 \\
\hline
\end{tabular}

Tablo 2. Araştırma alanı eğim sınıfları dağılımı.

\begin{tabular}{llll}
\hline Eğim Sınıfları & $\mathbf{( \% )}$ & \multicolumn{2}{c}{ Araştırma Alanı } \\
\cline { 3 - 4 } & & $\begin{array}{l}\text { Alan } \\
\text { (ha) }\end{array}$ & $\begin{array}{l}\text { Alan } \\
\text { (\%) }\end{array}$ \\
\hline Düz & $0-2$ & 22,47 & 3,19 \\
Az Eğimli & $2-5$ & 13,36 & 1,90 \\
Orta Eğimli & $5-12$ & 69,42 & 9,88 \\
Çok Eğimli & $12-20$ & 107,32 & 15,28 \\
Dik & $20-30$ & 160,56 & 22,87 \\
Sarp & $30-45$ & 165,08 & 23,49 \\
Pek Sarp & $45+$ & 164,36 & 23,39 \\
\hline Toplam & & 702,6 & 100 \\
\hline
\end{tabular}




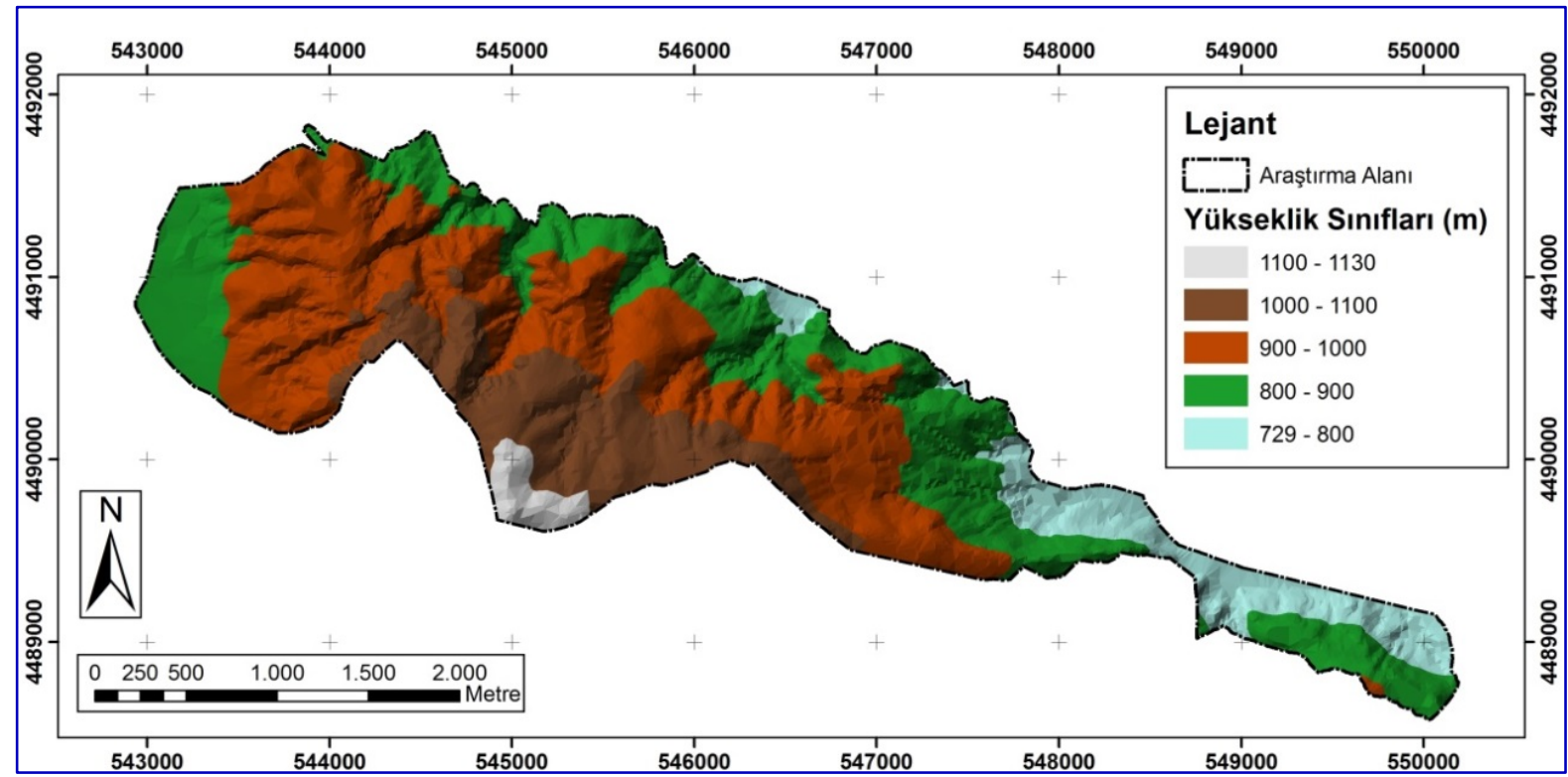

Şekil 2. Araştırma alanı yükseklik haritası.

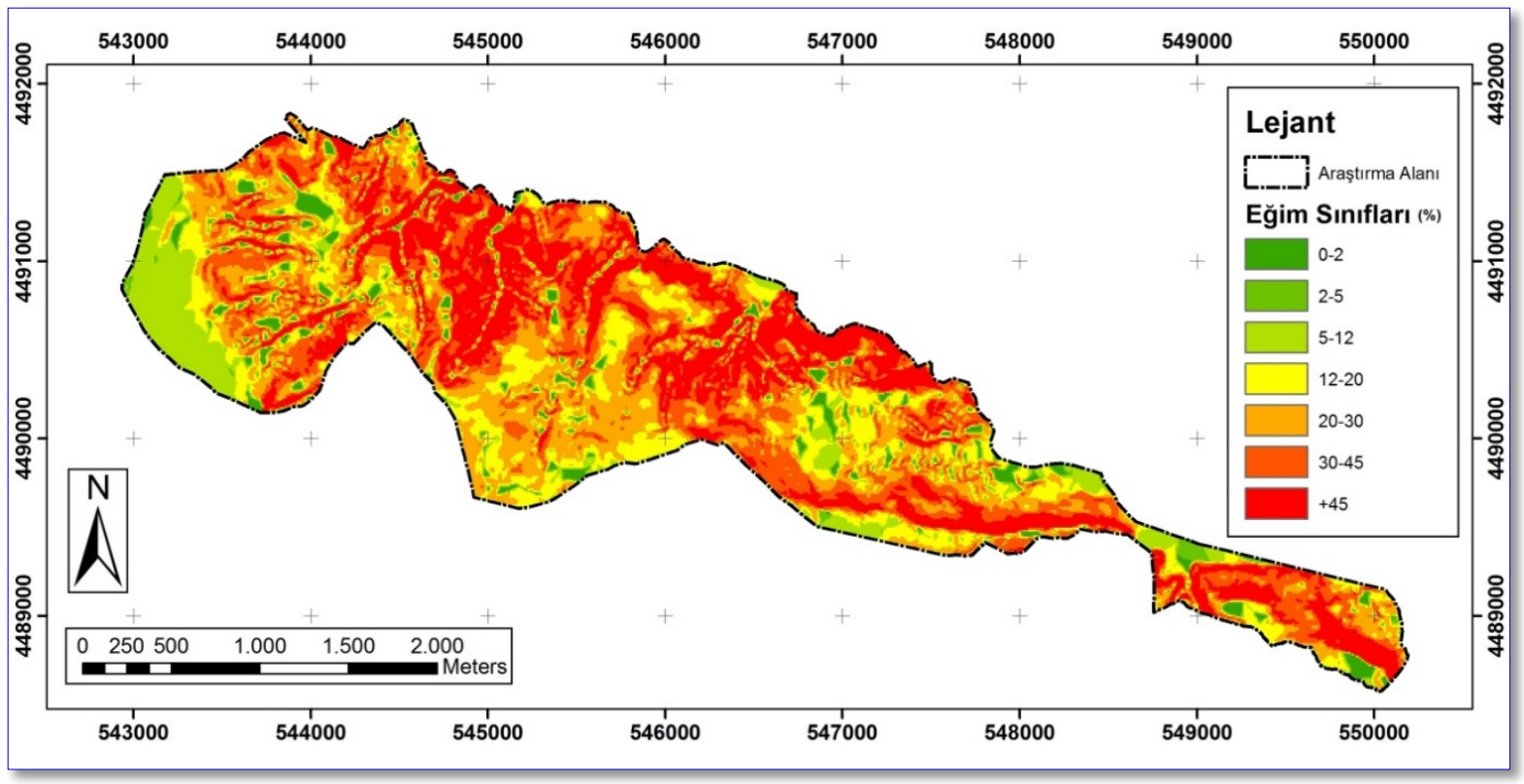

Şekil 3. Araştırma alanı eğim sınıfları haritası.

Araştırma alanı, Karadeniz nemli iklim kuşağından Orta Anadolu kurak iklim kuşağına geçiş zonu içerisinde yer almaktadır. Karadeniz ikliminin etkisi altında kalan yüksek dağlık bölgelerde kuru ormanlar ve geniş mera alanları, İç Anadolu kurak iklimin etkin olduğu bölgelerde ise bozkır bitki örtüsü hakimdir (Göl, 2002; OGM, 2011-2030; OGM, 2015). Araştırma alanında yıllık ortalama sıcaklık 10,5 ${ }^{\circ} \mathrm{C}$, ortalama yıllık toplam yağ $\mathrm{g}_{S} 486$ mm’dir (MGM, 2019). Thornthwaite iklim sınıflandırma modeline göre Çankırı DB'1db'3 rumuzu ile gösterilen "Kurak-yarı kurak, mezotermal, su fazlası yok veya pek az, denizel iklim etkisine yakın" bir iklim sınıfindadır (Göl, 2002; Tuttu ve Akkemik, 2017).

Çankırı ili toprakları, Karadeniz Bölgesi ve Orta Anadolu Bölgesi olarak hemen hemen iki eşit parçaya bölünür (Gökmen, 2007). Çankırı ilinin kuzeyi III. zamanda oluşmuş Oligosen-miyosen yaştaki jips serileri ile kaplıdır. Bu oluşum kalın ve kırmızı renkli bir taban konglomerası ile başlar, bunu açık renkli ve aralarında jips yatakları da bulunan kil ve marnlar izler (Blumenthal, 1948; Birgili ve ark., 1975; Akyürek ve ark., 1988). Araştırma alanında tuzlu ve jipsli ana kayalardan oluşmuş bir toprak yapısı bulunmaktadır. 
Bölge toprakları, orta ve hafif bünyeli, orta alkali (pH: 7.5-8.0), az tuzlu (EC: 2-4 dS/m Sat. Eks.), orta tuzlu (EC: 4-8 dS/m Sat. Eks.), orta kireçli (\%4-8 $\mathrm{CaCO}_{3}$ ), yüksek kireçli (\%8-15 $\mathrm{CaCO}_{3}$ ) ve organik madde miktarı düşük (\%1-2)'tür. Yüksek eğimli ve erozyona uğramış alanlarda topraklar sı̆̆ $(20-50 \mathrm{~cm})$, orta derin (50-90 $\mathrm{cm})$, iskeletli ve yetersiz $(20-50 \mathrm{~cm})$ fizyolojik derinliğe sahiptir (Göl, 2002).

Araştırma alanı, İran-Turan flora bölgesindedir. Türkiye’nin Önemli Bitki Alanı (ÖBA)'ndan 89. sırada bulunan "Çankırı'nın Jipsli Tepeleri” alanı içerisindedir. ÖBA, Kızılırmak'ın Kuzeyinde, Çankırı şehir merkezine yakın geniş jips çökeltileri üzerindedir. ÖBA florası zengin bitki çeşitliliği göstermez ve bozkır ile mezotrofik mera habitatlarının bir mozaiğini oluşturur. ÖBA florasında, Türkiye’ye endemik 41 takson yer alır. Bu taksonların çoğu Çankırı' nın tarihi adı 'Germanicopolis' ten esinlenerek adlandırılmış, dar yayılıştaki endemiklerin birçoğu yalnızca ÖBA’ ya özgüdür. ÖBA resmi olarak koruma altında değildir, otlatma ve tarıma dönüştürme baskısı alanı tehdit etmektedir (Tuttu ve Akkemik, 2017; Atay ve ark., 2021).

Araştırma alanında yaygın çalı türleri; Berberis crataegina DC. (Karamuk), Paliurus spina - christi P. Mill. (Karaçalı), Prunus spinosa L. (Çakal Eriği), Rosa canina L. (Kuşburnu), Cotoneaster nummularia Fisch. \& C. A. Mey. (Dağ Muşmulası), Ligustrum vulgare L. (Adi Kurtbağrı), Vitis sylvestris C. C. Gmel. (Yaban Asması), Rubus sp. (Böğürtlen), Jasminum fruticans L. (Sarı Çiçekli Yasemin) dir. Ağaç türleri ise Pinus nigra J. F. Arnold subsp. pallasiana (Lamb.) Holmboe var. pallasiana (Anadolu Karaçamı), Quercus infectoria G.Olivier (Mazı Meşesi), Juniperus oxycedrus L. subsp. oxycedrus var. oxycedrus (Katran Ardıcı), Crataegus monogyna Jacq. (Alıç), , Populus nigra L. (Kara Kavak), Elaeagnus angustifolia L. (İğde), Pyrus communis L. (Yabani Armut), Amygdalus communis L. (Badem), Robinia pseudoacacia L. (Yalancı Akasya) dır.

\subsection{Metot}

Araştırma alanına ait topografik, jeolojik, meşcere, toprak ve iklim verileri elde edilmiştir. Bu veriler ışığında, alanın Sayısal Yükselti Modeli (SYM) kullanılarak yayılım gösteren farklı eğim grupları, fizyoğrafik üniteler, rölyef ve bakı grupları belirlenmiştir. Harita ve iklim verileri üzerinde çalışılarak araştırmanın amacına uygun oyuntu erozyon alanları belirlenmiştir. Değişik zamanlarda yapılan ön arazi etütleri sonucunda da amaca en uygun oyuntu sahaları ve örneklemeye uygun oyuntu sahaları belirlenmiş̧tir.

Araştırma alanı Arazi Kullanım Türleri/Arazi Örtüsü (AKT/AÖ)'nün belirlenmesinde Landsat ETM+ (2011) uydu görüntüsünden yararlanılmıştır. $\mathrm{Bu}$ amaçla Google Earth üzerinde çalışma alanının sınırı belirlenmiştir. Belirlenen sınır içerisinde her bir AKT/AÖ için Google Earth’ den dört adet örnek alan (belirleyici nokta) alınmıştır. Alınan bu örnek alanlar Landsat ETM+ uydu görüntüsü üzerine aktarılarak uydu görüntüsü kontrollü sınıflandırmaya tabi tutulmuştur. Elde edilen veriler 1şı̆̆ında on sekiz adet oyuntu (kuru dere) ve bu oyuntulardan toplanan ağaç ve çalı örnekleri incelenmiştir. Araştırma kapsamında incelemeye alınan oyuntuların seçilmesinde stabilizasyon (durgunlaşma) aşamasına gelmiş olanlar tercih edilmiştir. Görcelioğlu (2003)' te oyuntularda stabilizasyon veya durgunlaşma durumunu, oyuntu tabanı boyunca denge eğimine ulaşıldığı, oyuntu tabanının ve yan yüzeylerin durgun duruma geldiği ve oyuntu içerisinde toprak erozyonundan korunmaya yetecek kadar vejetasyonun yerleşip geliştiği aşama olarak tanımlamıştır. Buna göre araştırma alanı içerisinde bu kriterlere uygun veya en yakın özelliklerdeki oyuntular belirlenmiştir. Oyuntularda koordinat, eğim, yükselti, oyuntu sediment durumu, yamaç göçmesi, oyuntu genişlik, derinlik, toplam uzunluk ile oyuntu içi ağaç ve çalı grupları arasındaki uzaklıklar inceleme karnelerine not edilmiştir. İncelemeler, oyuntunun mansabından membasına doğru yürüyerek yapılmıştır. Bunun için oyuntu içerisinde her $10 \mathrm{~m}$ aralıklı ve ağaç/çalı türüne denk gelindiği noktalarda gerekli ölçümler yapılmıştır. Ayrıca örnekleme noktalarının üst ve alt yönü fotoğraflanmıştır. Bitkilerden çiçek, meyve, tomurcuk, yaprak ve gövde organı örnekleri toplanmıştır. Örnekler naylon poşetlerde laboratuvara taşınmış, Çankırı Karatekin Üniversitesi, Orman Fakültesi, Orman Botaniği Anabilim Dalı Herbaryumu'nda teşhis edilmiştir.

\section{Bulgular}

\subsection{Araştırma alanı arazi kullanım türü/arazi örtüsü (AKT/AÖ)}

Araştırma alanı olarak belirlenen 702,6 ha'lık bölgenin uydu görüntüsü kontrollü sınıflandırma (Kappa Değeri: 0,9222, Toplam Sınıf Doğruluk Değeri: \%9, 4,17) sonuçlarına göre AKT/AÖ dağılımı, mera \%47,8, kuru tarım \%25,5, bozuk orman ve çalılık \%16,9 ve yerleşim \%9,8'dir (Şekil 4). Alanda, oyuntular ve içinde bulundukları meralar serbest otlatmaya açık olup, çalı ve bodurlaşmış ağaç bireyleri yayılış göstermektedir. Alanın bazı bölümlerinde erozyon kontrol ve ağaçlandırma çalışmaları yürütüldüğü belirlenmiştir. Bu alanlar koruma altına alınmış, ancak ağaçlandırma çalışmalarında yeterli başarı sağlanamamıştır. 


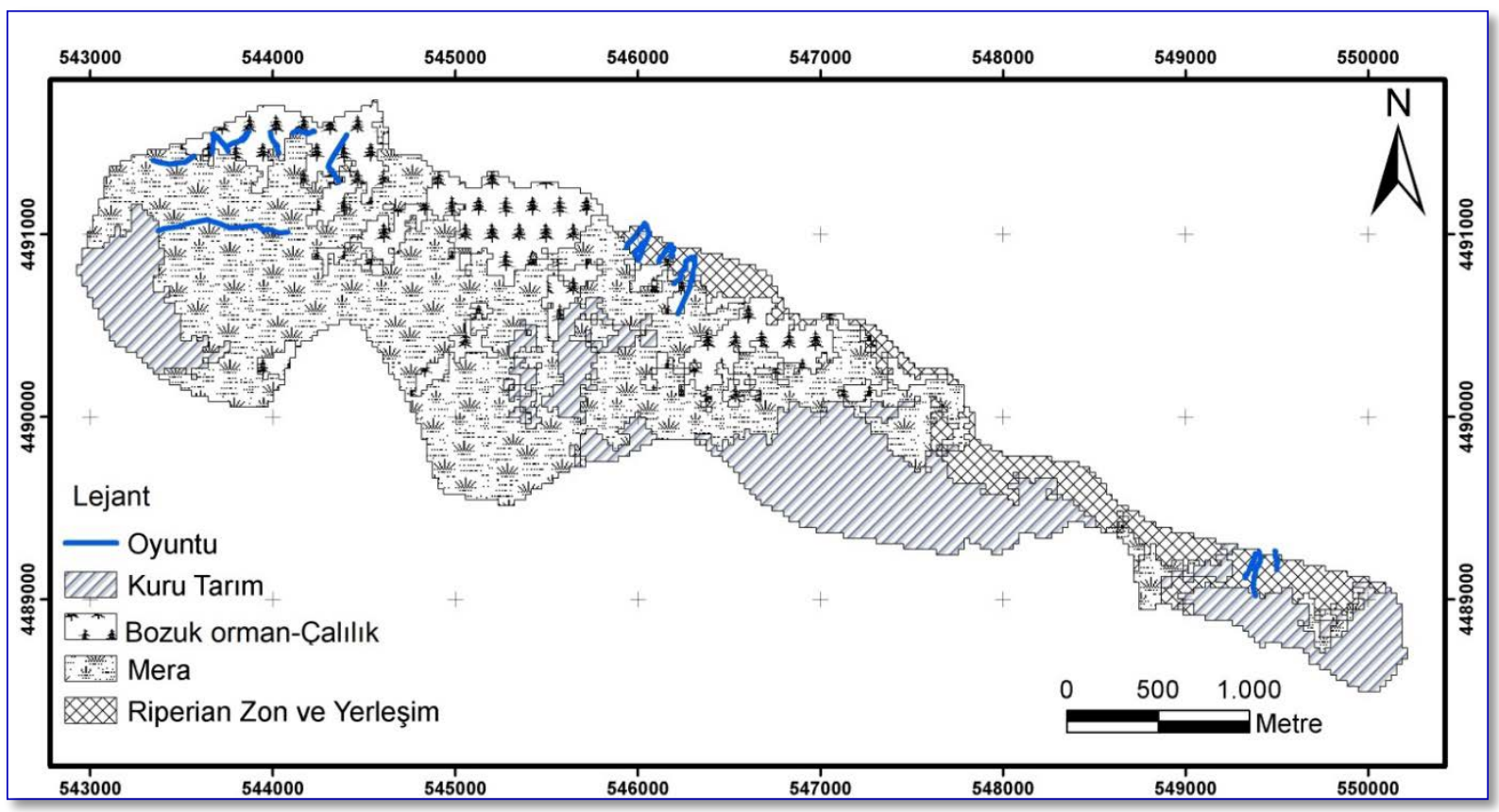

Şekil 4. Landsat ETM+ uydu görüntüsü kontrollü sınıflandırmaya göre araştırma alanında incelenen oyuntular ve AKT/AÖ dağılımı.

\subsection{Oyuntu özellikleri}

Oyuntu gelişim aşamalarını tamamlamış ve durgunlaşma aşamasında olan toplam 18 adet oyuntu araştırmaya konu edilmiştir. Bu oyuntuların sekiz adedi kuzey bakıda, üç adedi doğu bakıda ve yedi adedi batı bakıdadır. Oyuntularda yükseklik 787-989 m arasında değişmektedir. Oyuntu başlangıç noktası olarak en yüksek rakım kuzey bakıdadır. Oyuntu tabanı (ağız) olarak en düşük yüksseklik $735 \mathrm{~m}$ olup doğu bakıdadır. Oyuntularda yüksselti farkının (başlangıç ve bitiş noktası) en yüksek $(99 \mathrm{~m})$ görüldüğü yer ise batı bakıdadır.

Tüm oyuntular birlikte değerlendirildiğinde uzunluklar 120-700 m arasında değişmektedir. En uzun (698 m) oyuntu kuzey bakıda, en kısa (122 m) oyuntu ise batı bakıdadır. Genel olarak kuzey bakılı oyuntular daha uzun iken, batı bakılı oyuntular daha kısadır.

Oyuntu eğimleri \%13-62 arasında değişim göstermiştir. En yüksek eğimli oyuntular batı bakıda, en düşük eğimli oyuntular ise kuzey bakıda belirlenmiştir. Oyuntu eğimleri memba bölgelerinde \%6-8, mansap bölgesinde \%13-16 arasında değişmektedir. Çalışılan oyuntularda ortalama eğim en yüksek (\%35) batı bakıda, en düşük (\%30) kuzey bakıda görülmüştür. Bütün oyuntularda memba kısmındaki eğimin yüksek olduğu yerlerde ağaç ve çalı türleri tek birey halinde görülürken, eğimin düşük olduğu mansap bölgelerinde gruplaşmaların arttığı ve bitki boylarının uzun olduğu tespit edilmiştir. Mansap kısmında eğimin yüksek olduğu yerlerde türler birey veya grup halinde bulunmaktadır. Doğu bakılı oyuntuların eğimin yüksek olduğu mansap kısmında tür çeşitliliği yüksek ve bitkiler arası mesafe daha kısadır. Kuzey ve batı bakılı oyuntuların mansap bölgesinde görülen tür çeşitliliği ve gruplaşma daha az olup, bitkiler arası mesafe uzun ve bitki boyları kısadır.

Oyuntularda ortalama genişlik 4 m’dir. Oyuntuların memba bölgelerinde en yüksek (9 m) genişlik kuzey bakıda, en düşük $(1 \mathrm{~m})$ genişlik ise batı bakıdadır. Mansap bölgesinde ise en yüksek $(5 \mathrm{~m})$ genişlik kuzey bakıda, en düşük $(1 \mathrm{~m})$ genişlik doğu bakıdadır. Bütün oyuntulara bakıldığında, genişliğin oyuntunun orta bölgelerinde daha yüksek olduğu ve bu bölgelerde bitki grupları arası mesafenin düşük olduğu tespit edilmiştir. Oyuntuların orta bölgelerinde eğim düşük, sedimentasyon yüksek, bitki gelişimi daha iyidir.

Oyuntularda ortalama derinlik 1,5 m’dir. En yüksek (2 m) oyuntu genişliği batı bakıda belirlenmiştir. Oyuntuların memba bölgesinde en yüksek (6-8 m) derinlik doğu ve batı bakılarda; mansap bölgesinde en yüksek derinlik üç bakıda da $1 \mathrm{~m}$ olarak belirlenmiştir. Kuzey bakılı oyuntularda derinlik daha yüksektir. Kuzey bakılı oyuntuların memba bölgelerinde türlerin tek birey olarak yayılış göstermiştir. Batı ve doğu bakılı oyuntularda tek türe ait bireyler veya grup bitki toplulukları bulunmaktadır. Oyuntuların mansap bölgeleri incelendiğinde, kuzey ve batı bakılı oyuntularda derinliğin yüksek olduğu yerlerde bitkiler arası gruplaşmalara rastlanırken, doğu bakılı oyuntularda mansap bölgesinde tek tür bireyler olduğu tespit edilmiştir. Oyuntular, 
derinliklerine göre sınıflandırıldığında kuzey bakılı oyuntular sel yarıntısı, doğu ve batı bakılı oyuntular ise sel dereciği sınıfına girmekte olup; Görcelioğlu (2003)' na göre yapılan sınıflandırmada; kuzey bakılı oyuntular sı̆̆ oyuntular, doğu ve batı bakılı oyuntular ise derin oyuntulardır.

Üç bakıda da oyuntu içerisinde taşlılık orta derecede mevcuttur. Batı bakılı oyuntuların içerisinde kum - çakıl orta derecede bulunmakta, yamaç göçmesi ve taban oyulması yoktur. Kuzey bakılı oyuntularda kum - taş - çakıl ve kaya yüksek miktarda bulunmaktadır. Bazı oyuntularda mansap bölgesinden memba bölgesine doğru çıkarken taşlılık artmakta ve sol sahilde kayalık alanlara rastlanmaktadır. Doğu bakılı oyuntularda taşlılık ve kayalık durumu yüksektir. Mansap bölgesinde sağ ve sol sahilde kayalık alanlar bulunmaktadır. Bu bölgede taban oyulması ve kıyı oyulması mevcuttur. Taban oyulması ana kayaya kadar ilerlemiş bulunmaktadır.

\subsection{Bakı ve oyuntuya göre ağaç ve çalı türleri}

Araştırma alanında incelenen kuzey bakıda, sekiz adet oyuntuda 160 adet, doğu bakıda, üç adet oyuntuda 62 adet ve batı bakıda yedi adet oyuntuda 119 adet ağaç ve çalı türlerinden oluşan toplam 341 adet bitki örneği toplanmıştır. Toplanan bitki örneklerinin 145 adedi ağaç, 196 adedi ise çalı türlerine aittir. Bu örnekler, 11 familyaya ait toplam 18 farklı türden oluşmaktadır. Araştırma alanındaki tüm oyuntular birlikte değerlendirildiğinde, Rosaceae (Gülgiller) \%39 (7 adet) ve Oleaceae (Zeytingiller) \%11 (2 adet) familyalarına ait türler en yüksek yayılışa sahiptir. Geriye kalan türlerin ise \% 6 oranlarında Fabaceae, Vitaceae, Pinaceae, Salicaceae, Elaeagnaceae ve \%5 oranlarında Berberidaceae, Rhamnaceae, Cupressaceae, Fagaceae familyalarına ait olduğu tespit edilmiştir (Şekil 5).

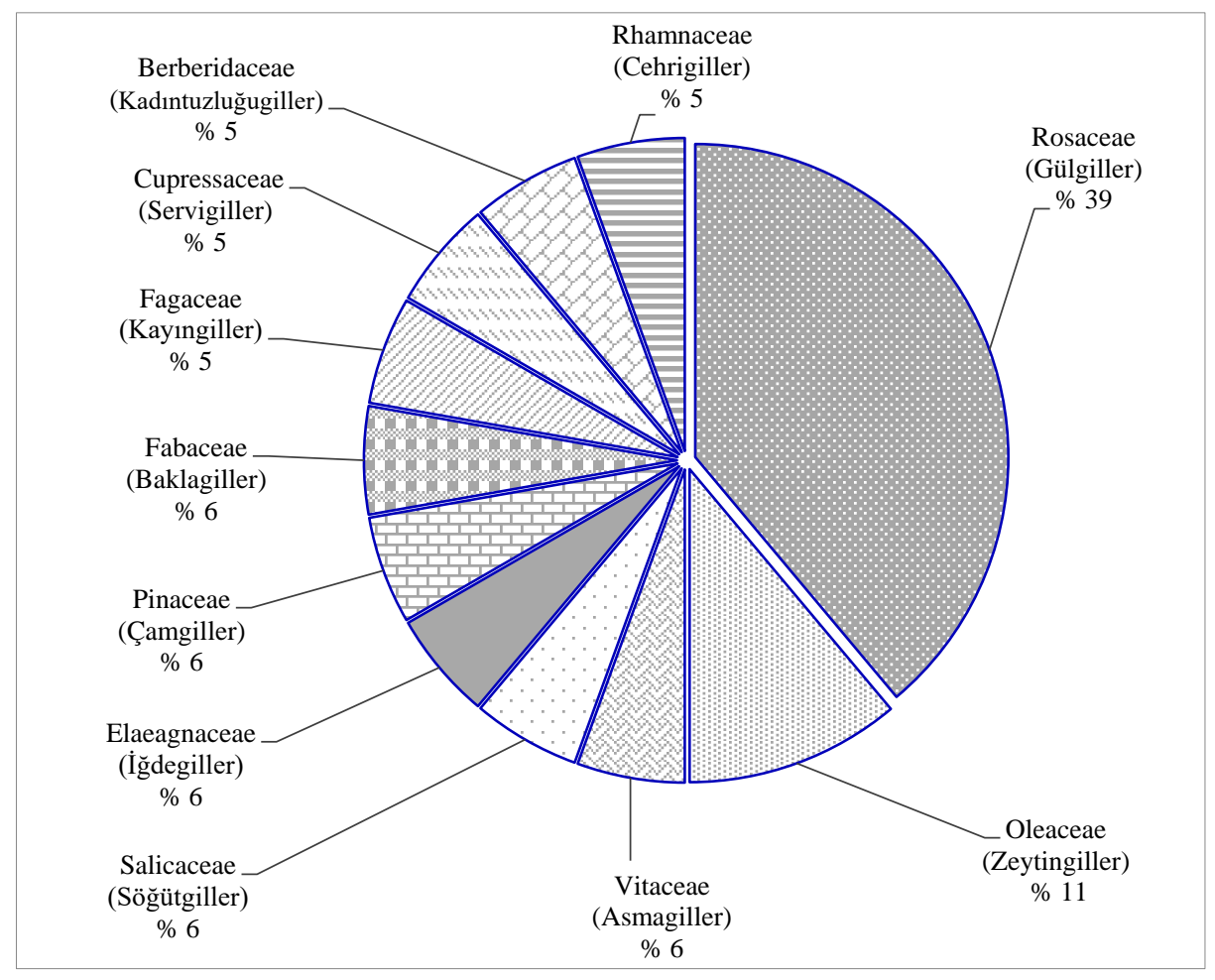

Şekil 5. Oyuntu içi ve yakın çevrelerinde yayılış gösteren familyalar ve yayılış oranları.

Araştırma alnında, Berberidaceae (Kadıntuzluğugiller) familyasına ait karamuk, Rhamnaceae (Cehrigiller) familyasına ait karaçalı ve Rosaceae (Gülgiller) familyasına ait alıç türlerinin her üç bakıda ve tüm oyuntu içlerinde olduğu belirlenmiştir. Oyuntu içi ve çevresinde en düşük yayılış gösteren türler ise Vitaceae (Asmagiller) familyasına ait yabani asma ve Fabaceae (Baklagiller) familyasına ait yalancı akasya olduğu görülmüştür.

Fagaceae (Kayıngiller) ve Cupressaceae (Servigiller) familyasına ait türler sadece kuzey bakıda, Fabaceae (Baklagiller) familyasına ait türler ise sadece batı bakıda yayılış göstermiştir. Doğu bakıya özgü yayılış gösteren bir familyaya ait tür tespit edilememiştir. Çalışma alanı içerisinde kuzey bakıda en yüksek yayılış gösteren türler mazı meşesi, katran ardıcı ve karaçalıdır. Aynı zamanda dağ muşmulası, çakal eriği, sarıçiçekli yasemin ve yabani asma sadece kuzey bakıda yayılış gösteren türlerdir. Kara kavak, kuşburnu ve Anadolu karaçamı en 
düşük yayılış gösteren türlerdir. Doğu bakıda en yüksek yayılış karamuk ve alıç, en düşük yayılış ise karaçalı, bögürtlen ve yabani armut türleridir. Batı bakıda ise karamuk, alıç ve Anadolu karaçamı en yüksek yayılış gösteren türlerdir. Yalancı akasya ve badem batı bakıya özgü türlerdir. Adi kurtbağrı ve kuşburnu ise batı bakıda en düşük yayılış yapan türlerdir.

Tüm oyuntular birlikte ele alındığında 8 adet farklı ağaç türü ve 10 adet farklı çalı türü alanda yayılış göstermiştir. Farklı bakılara göre incelendiğinde, kuzey bakıda 6 adet ağaç ve 10 adet çalı, doğu bakıda 2 adet ağaç ve 3 adet çalı, batı bakıda da 7 adet ağaç ve 5 adet çalı türü tespit edilmiştir. Kuzey ve doğu bakıda yüksek oranda çalı türlerine rastlanırken, batı bakıda ise daha yüksek yayılışta ağaç türlerine rastlanmıştır. Tüm oyuntular içerisinde ağaç türleri bakımından alıç (\%15), Anadolu karaçamı (\%12) en yüksek, yalancı akasya $(\% 0,3)$ ise en düşük yayılış gösteren türlerdir. Araştırma alanı içerisinde Anadolu karaçamı bireylerinin doğal olarak yetiştiği tespit edilmiştir. Anadolu karaçamı en yüksek yayılışını batı bakılı oyuntular içerisinde yapmıştır. Mazı meşesi ve katran ardıcı ise sadece kuzey bakılı oyuntu içlerinde yayılış göstermiştir. Çalı türleri incelendiğinde, karamuk (\%22) ve karaçalı (\%18) en yüksek yayılış gösteren türlerdir. Bunun dışında böğürtlen, kuşburnu, sarıçiçekli yasemin, çakal eriği ve dağ muşmulası alanda yayılış göstermiştir. Ayrıca yabani armut ve badem oyuntu içlerinde doğal olarak gelişmiştir (Şekil 6).

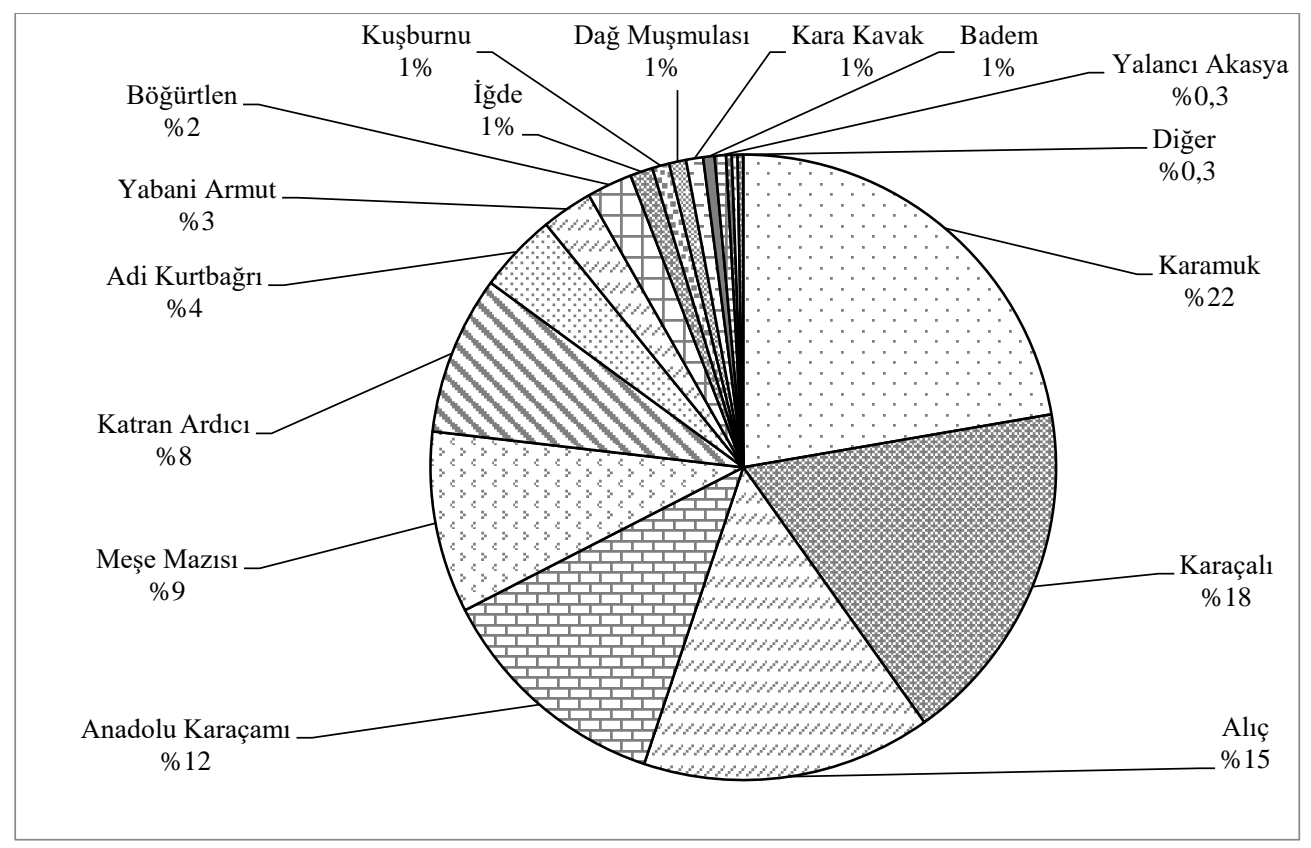

Şekil 6. Oyuntuların içi ve çevresinde yayılış gösteren ağaç ve çalı türlerinin dağılımı

\section{Tartışma ve Sonuç}

İç Anadolu gibi kurak ve yarı kurak bölgelerde erozyon önleme ve ağaçlandırma konusunda önemli çalışmalar yapılmaktadır. Ekolojik dengenin bozulduğu bu ve benzeri alanlarda doğal yetişen türleri kullanmak en uygun yöntemlerden biridir. Oyuntu ıslah çalışmalarında bitkilendirme için alanda doğal olarak yetişmiş ağaç ve çalı türlerinin tercih edilmesi çalışmalarda başarıyı artıracaktır. Araştırmaya konu edilen durgunlaşma aşamaşına gelmiş oyuntularda çalı türlerinin daha yaygın olduğu dikkat çekmektedir. Kuzey ve batı bakıda tüm alanda yayılış gösteren türler dışında sadece bu bakılara özgü bitki türlerinin olduğu belirlenmiştir. Bu durum bitki türü seçiminde bakının önemli bir faktör olduğunu göstermektedir. Yılmaz (2009)'da vadilerin sahip oldukları içe bakar yamaçlar, vadi içlerindeki rüzgar hareketleri ve gölgelik alanların oluşması bakımlarından, bitkilendirme çalışmalarında dikkat edilmesi gereken alanlar olduğunu belirtmektedir. Kuzey bakıda bitki yoğunluğu ve bitki boyları daha yüksektir. Bu durumu, Atalay (2001)'de yarı kurak bölgelerde genellikle gölgeli (kuzey - doğu) bakılarda toprağın nem miktarının daha yüksek olması ile açıklamaktadır. Özellikle oyuntuların mansap bölümünde, yoğun ve gruplar halinde çalılar yetişmiştir. $\mathrm{Bu}$ bölgelerde çalılar oyuntunun ilerleyişini yavaşlatmış ve arkalarında sediment depolayarak erozyonu önlemiştir. Bazı oyuntularda ağaç bireyleri de olmasına karşın çalı türleri kadar yaygın olmadıkları ve yeterli gelişimi sağlayamadıkları görülmüştür.

Bitki örtüsünden yararlanmak için öncelikle onun tanımlanması gerekmektedir. Bununla ilgili çalışmalar aynı zamanda, ekolojik dengenin hassas olduğu alanlarda vejetasyona nasıl müdahale edileceğini de tespit etmektedir 
(Arslantürk, 2007). Bunun için bu çalışmada, oyuntu içi ve yakın çevresinde doğal olarak yetişmiş ağaç ve çalı türleri incelenmiştir. Çalışma sonunda, çalı türlerinin daha yaygın oldukları sonucuna varılmıştır. Konz ve ark. (2010)'da göre çalı örtüsü ile kaplı arazilerde, çıplak arazilere göre oyuntu erozyonun daha az olduğunu belirtmiştir.

Araştırma alanında, kuraklığın yanı sıra, bitki gelişimini kısıtlayan etmenlerin başında tuz ve jips ana kaya yapısı gelmektedir. Türkiye'de jipsli ana kaya yapısı Sivas - Çankırı, Sivas - Erzincan arasında ve Ankara Eskișehir civarında büyük alanlar kaplamaktadır (Akpulat, 2003). Bu tip ana kaya yapısına sahip alanlarda bitki yetiştirmek ve özellikle oyuntu alanlarında bitkilendirme yapmak en zor ve hassas çalışmayı gerektirmektedir. Erşahin ve Karahan (2016)'da jipsin toprakta fidelerin çıkışını engelleyen sert bir yüzey kabuklanmasına neden olduğunu ve belirli alanlarda toprakta gözenekliliği azaltarak bitki kök hareketini sınırlayabileceğini belirtmişlerdir. Araştırma sonucunda da görüldüğü gibi alanda önceden yetişmiş ağaç veya çalı türlerinin tespiti ve gelişim özelliklerinin incelenmesi gerekmektedir. Böylece oyuntu ıslah çalışmaları kapsamında yapılacak bitkilendirme için yöreye uyum sağlamış türlerin kullanılması gerekmektedir.

Anakaya özellikleri oyuntuların oluşum ve gelişim sürecini etkilemektedir. Erozyonla ilgili yapılacak olan çalışmalarda öncelikle toprak özellikleri ve erozyon eğilimleri ortaya konulmalıdır. Bu nedenle oyuntu sslah çalışmaları öncesi, erozyon bölgesinin jeolojik, jeomorfolojik ve özellikle toprak özellikleri detaylı etüt edilmelidir. Diğer önemli bir konu ise oyuntu içerisinde depolanan veya taşınan sediment özellikleridir. Oyuntu içi ve çevresinden koparılarak hareket eden bu malzeme mekanik çalışmalarda yöntem ve kullanılacak malzemeyi dikte etmektedir. Aynı zamanda daha sonra yürütülecek bitkilendirme için kullanılacak tür seçiminde de önem taşımaktadır.

Yarı kurak iklimlerde bakının erozyona duyarlılık ve erozyon miktarı üzerinde etkisi oldukça fazladır (Şahin ve ark., 2014). Bu etkin özellikleri nedeni ile bakı dolaylı olarak bölgenin bitki örtüsünü de etkilemektedir. Bu nedenle yapılacak çalışmalarda tür seçiminde bakı faktörü dikkate alınmalıdır. Araştırma sonucu elde edilen bulgular dikkate alındığında bazı bakılarda ağaç türleri yaygınlık gösterirken, bazı bakılarda çalı türleri öncelik kazanmıştır. Kuzey bakıda nem istekleri yüksek ve dona dayanıklı türler yayılış göstermiştir. Oyuntu içi bitki yayılışında eğim, sediment ve oyulma şiddeti temel faktörlerdir. Oyuntuların mansap ve memba bölümlerinde farklı bitki gelişim özellikleri ortaya çıkmıştır. Buna göre oyuntu ıslah çalışmalarında, bakı durumu ve bitki türü birlikte düşünülmelidir.

Anadolu karaçamı, gerek yaz sıcaklığına ve kuraklığına, gerekse kış soğuklarına karşı dayanıklı olup, toprak istekleri bakımından da yetingendir (Özkan ve ark., 2011). Anadolu karaçamı, bu özellikleri nedeni ile araştırma alanı içerisinde doğal olarak yetişebilmiştir.

Yıldız (2016)'da, yarı kurak bölgelerde en şiddetli erozyonun bitki örtüsünden yoksun dönemde meydana geldiğini ve daha çok ince malzemenin taşındığı belirtmiştir. Yürütülen araştırma kapsamında incelenen oyuntularda taşınan sediment daha çok kum ve çakıl olduğu belirlenmiştir. Özellikle eğimin çok yüksek olduğu oyuntularda yer yer taş ve kaya taşınmasının da olduğu görülmüştür. Oyuntu içi taşınan malzemenin özelliği, erozyon kontrol yöntemini ve dikilecek ağaç ve çalı türünü doğrudan etkilemektedir. Schiechtl ve Görcelioğlu, (1971)'de oyuntu içi ıslah çalışmalarında sediment hareketinin mekanik yollarla önlenmesini, daha sonra bitkilendirme yapılmasını önermişlerdir.

Oyuntu erozyonu ile mücadelede önce mühendislik yapıları ve daha sonra bitkilendirme yapılarak sedimentasyon \%75 azalmıştır (Hao ve Qiangguo, 2006). Yürütülen araştırmalara göre Martinez-casasnovas ve ark. (2009)'de \%26,5, Bastola ve ark. (2018)'de \%23-69 oranında oyuntu içerisinde gelişen vejetasyonun taşınan sediment miktarını azalttığı belirtilmiştir. Goulart ve ark. (2006), Loschi ve ark. (2010) ve Frankly ve ark. (2019)'da oyuntu erozyonu ile mücadelede kullanılacak bitkilerin ekosisteme kolay adapte olabilen türlerden seçilmesi gerektiğini belirtmişleridir. Kurak ve yarı kurak ağaçlandırma sahalarında alan seçimi kadar, doğal seleksiyon sonucu bölgeye adapte olmuş türler kullanılmalıdır (İmal ve ark., 2006; Hao ve Qiangguo, 2006). Göl (2016)' da Türkiye'nin kurak ve yarı kurak bölgelerinde tuz, kireç, jips, sı ğ ve iskeletli toprak özelliklerinin bitki gelişimini kısıtlayıcı faktörler olarak sıralamaktadır. $\mathrm{Bu}$ araştırmada, birçok ekolojik özelliğin karmaşık ilişkileri sonucunda oyuntu içi ve çevresinde kurakçıl bitki topluluklarının gelişim gösterdiği belirlenmiştir. Ayrıca, diğer dikkat çekici bir sonuç ise aynı oyuntunun, mansap veya memba bölgesinde dahi tür çeşitliliği ve bitki gelişimi bakımından farklılıkların olduğudur. Oyuntu ıslah çalışmalarında her bir oyuntu kendi iç özelliklerine göre değerlendirilmelidir. Her bir oyuntu bireysel olarak ele alındığı gibi, aynı zamanda oyuntunun mansap ve memba bölgeleri de farklı ele alınmalıdır. Genel olarak oyuntularda memba bölgesi toprak özellikleri (özellikle derinlik bakımından) daha olumsuz ve kuraklık daha etkendir. Buna karşılık oyuntuların mansap bölgesi göreceli olarak daha nemli ve daha derin topraklıdır. Bu durum, oyuntu mansap 
bölgelerinin bitki gelişimini bakımından daha iyi özelliklere sahip olmasını sağlamaktadır.

Yamaç eğiminin artması erozyon oluşum hızını yükseltmektedir (Oğuz, 1997; Doğan, 2011; Şahin ve ark. 2014). Yürütülen bu araştırma sonuçları da yüksek eğimli yamaçlarda oluşan oyuntuların daha derin ve geniş morfolojiye sahip olduklarını göstermiş̧ir. Araşırma alanında doğal ve antropojen etkiler sonucunda, potansiyel ve aktif oyuntu erozyon sahaları yaygındır. Bu alanlar aşırı derece bozuk olduğu için sslah edilmelidir. Toprakların erodibilite özellikleri farklıdır. Bu nedenle aynı ekolojik koşullarda bile topraklar farklı erozyon şiddeti gösterirler (Aydın, 2000). Yürütülen bu araştırma sonuçları da göstermektedir ki, doğu bakıda oyuntu oluşum ve gelişimi daha şiddetlidir. Ayrıca, bu bakıda oyuntu içi tür sayısı ve çeşitliliği diğer bakılara göre daha yetersizdir.

\section{Teşekkür}

$\mathrm{Bu}$ araştırma, ÇKÜ, Fen Bilimleri Enstitüsü’nde yürütülen Yüksek Lisans çalışmasının bir bölümüdür Araştırmanın farklı aşamalarında desteklerini sunan Arş. Gör. Dr. Semih EDİş'e, Arş. Gör. Dr. Gamze TUTTU'ya Doç. Dr. Ender BUĞDAY'a, Doç. Dr. Serhat URSAVAŞ'a ve Doç. Dr. Alkan GÜNLÜ’ye, teşekkür ederiz.

\section{Kaynaklar}

1. Akpulat, H.A. (2003). Sivas İli Jipsli Alanların Florası. Doktora Tezi, Cumhuriyet Üniversitesi, Fen Bilimleri Enstitüsü, Biyoloji Anabilim Dal, Sivas.

2. Akyürek, B., Akbaş, B., Değer, Z. (1988). 1/100.000 Ölçekli Açınsama Nitelikli Türkiye Jeoloji Haritaları Servisi, Çankırı E-16 Paftası, MTA Gn. Md. Jeoloji Etüt Dairesi, Ankara.

3. Arslantürk, N. (2007). Sivrihisar Dağları' nın (Eskişehir) Bitki Ekolojisi ve Bitki Sosyolojisi Yönünden Araştırılması. Doktora Tezi, Ankara Üniversitesi, Fen Bilimleri Enstitüsü, Biyoloji Anabilim Dalı, Ankara.

4. Atalay, İ. (2011). Türkiye’ de Yarı kurak Bölgelerin Ekolojik Özellikleri ve Ağaçlandırmada Tür Seçimi, Kurak ve Yarı kurak Alan Yönetimi Çalıştayı, Nevşehir.

5. Atalay, İ. (2014). Türkiye'nin Ekolojik Bölgeleri (Genişletilmiş 2. Baskı). Meta Basım Matbaacılık Hizmetleri, İzmir. ss: 20-36.

6. Atay, S., Doğruöz, D., Orhun, C., Dağdeviren, Ö. (2009). ÖBANET Gönüllü Klavuzu, Dönence Basım ve Yayın Hizmetleri, http://obanettr.org/images/pdf/Obanet_kilavuz.pdf, ISBN/EAN: 978-90-814408-2-0, İstanbul. s: 11-12, (Ziyaret Tarihi: 17.03.2021).

7. Aydın, M. (2000). Giresun - Yağlıdere Havzasında Farklı Anamateryaller Üzerinde Gelişen Toprakların Erozyon Eğilim Değerleri ve Vejetasyon Yapısı Üzerine Araştırmalar. Yüksek Lisans Tezi, Karadeniz Teknik Üniversitesi, Fen Bilimleri Enstitüsü, Orman Mühendisliği Anabilim Dalı, Trabzon.

8. Babalık, A.A. (1999). Erozyon ve Türkiye. T.C. Orman Bakanlığı Teknik Bülteni, Sayı: 6, Sayfa: 3, Ankara

9. Bastola, S., Dialynas, Y.G., Bras, R.L,, Noto, L.V., İstanbulluoglu, E. (2018). The role of vegetation on gully erosion stabilization at a severely degraded landscape: A case study from Calhoun Experimental Critical Zone Observatory. Geomorphology, 308: 25-39.

10. Birgili, Ş., Ünalan, G., Yoldaş, R. (1975). Çankırı-Çorum Havzası'nın Jeolojisi ve Petrol Olanakları, MTA Genel Müdürlüğü Raporu, Rap., No: 5621, Ankara.

11. Blumenthal, M. (1948). Bolu Civarı ile Aşağı Kızılırmak Mecrası Arasındaki Kuzey Anadolu Silsilesi’nin Jeolojisi, MTA Genel Müdürlüğü Raporu, Rap No. 2026, Ankara.

12. Capra, A., Scicolone, B. (2002). Ephemeral gully erosion in a wheat-cultivated area in Sicily (Italy). Biosystems Engineering, 83 (1): 119-126

13. Celilov, C., Dengiz, O. (2019). Erozyon duyarlılık parametrelerinin farklı enterpolasyon yöntemleriyle konumsal dağılımlarının belirlenmesi: Türkiye, Ilgaz Milli Park toprakları. Türkiye Tarımsal Araştırmalar Dergisi, 6(3): 242-256.

14. ÇEM. (2017). Erozyonla Mücadele Eylem Planı 2013 - 2017. Orman ve Su İşleri Bakanlı̆̆ı, 96 s, Ankara.

15. Çetik, N. (1985). İç Anadolu Vejetasyonu ve Ekolojisi. Selçuk Üniversitesi, Fen Edebiyat Fakültesi Yayın No: 1, s.496, Konya. Doğan, O. 2011. Türkiye'de Erozyon Sorunu Nedenleri ve Çözüm Önerileri. Bilim ve Aklın Aydınlığında Eğitim, 134: 62-69.

16. Erşahin, S., Karahan, G. (2016). Jips: Özellikleri, Çevresel Davranışları ve Toprak Islah Maddesi Olarak Kullanımı. Anadolu Orman Araştırmaları Dergisi, 2(1-2); 45-53. 
17. Frankl, A., Nyssen, J., Adgo, E., Wassie, A., Scull, P. (2019). Can woody vegetation in valley bottoms protect from gully erosion? Insights using remote sensing data (1938-2016) from subhumid NW Ethiopia. Regional Environmental Change, 19: 2055-2068.

18. Gomide, P.H.O., Silva, M.L.N., Castro, G.C. de, Soares, C.R.F.S., Olivera, A.H., Curi, N. (2014). Vegetation characterization in gully areas as basis for soil conservation. Ciênc. Agrotec., Lavras, 38(2): 149-159.

19. Gökmen, B. (2007). Çankırı ili coğrafyası. Ankara Üniversitesi, Sosyal Bilimler Enstitüsü, Çoğrafya (Türkiye Coğrafyası) Anabilim Dalı, Doktora Tezi, Ankara.

20. Göl, C. (2002). Çankırı-Eldivan yöresinde arazi kullanım türleri ile bazı toprak özellikleri arasındaki ilişkiler. Ankara Üniversitesi, Fen Bilimleri Enstitüsü, Doktora Tezi. Ankara.

21. Göl, C., Yel, S. (2016). Ağaçlandırma Çalışmalarında Farklı Toprak Hazırıı̆ı Uygulamalarının Fidan Gelişimi Üzerine Etkilerinin Değerlendirilmesi. Süleyman Demirel Üniversitesi, Türkiye Ormancılık Dergisi, 17(2): 125-131.

22. Görcelioğlu, E. (2003). Sel ve Çı̆̆ Kontrolü. İstanbul Üniversitesi Orman Fakültesi Yayınları, 384 s, İstanbul.

23. Hao, C., Qiangguo, C. (2006). Impact of hillslope vegetation restoration on gully erosion induced sediment yield. Science in China: Series D, Earth Sciences, 49(2): 176-192.

24. İmal, B., Yılmaz, S., Sağlıcak, Y., Kondur, Y., Öner, N., Yılmaz, S. (2006). Çankırı (Tümçam)’ da Yarı Kurak Ağaçlandırma Çalışmalarının Değerlendirilmesi. Türkiye' de Yarı Kurak Bölgelerde Yapılan Ağaçlandırma ve Erozyon Kontrolü Uygulamalarının Değerlendirilmesi Çalıştayı, 1(15), Ürgüp.

25. Karagöz, A., Tercan, E., Erpul, E., Türkeş, M., Dengiz, O., Doğan, O., Öztaş, T. (2017). Türkiye Çölleşme Modeli. T.C. Orman ve Su İşleri Bakanlığı, Ankara.

26. Kaş, B.S. (2016). Erozyon Kontrol Alanlarında Bitkilendirme Çalışmalarının Toprak Özellikleri Üzerine Olan Etkileri. Kastamonu Üniversitesi, Fen Bilimleri Enstitüsü, Orman Mühendisliği Anabilim Dalı, Yüksek Lisans Tezi, Kastamonu.

27. Khoshoo, T.N., Tejwani, K.G. (1993). World Soil Erosion and Conservation, David Pimentel (Edt.), Cambridge University Press, ISBN: 978 - 0 - 521 - 10471 - 5, Cambridge, UK.

28. Kırdar, E., Özel, H.B., Ertekin, M., Demir, N. (2011). Kurak ve Yarı Kurak İklim Bölgelerinde Ağaçlandırma Çalışmaları (Çankırı Örneği) Üzerine Değerlendirme, Orman ve Su İşleri Bakanlığı, Çölleşme ve Erozyonla Mücadele Genel Müdürlüğü, Kurak ve Yarı Kurak Alan Yönetimi Çalıştayı Sonuç Bildirgesi ve Bildiriler, Nevşehir (Ürgüp), 5 - 8 Aralık 2011, Ankara, s: 124-137.

29. Konz, N., Baenninger, D., Konz, M., Nearing, M., Alewell, C. (2010). 'Process Identification of Soil Erosion in Steep Mountain Regions’ Hydrol. Earth Syst. Sci., 14: 675-686.

30. Loschi, R.A., Pereira, J.A.A., Machado, E.L.M., Carlos, L., Santos, R.M. (2011). Floristic and structural variations of a gully at itumirim, minas gerais. Cerne, 16(4): 479-498.

31. Martínez-Casasnovas, J.A., Ramos, M.C., García-Hernández, D. (2009). Effects of land-use changes in vegetation cover and sidewall erosion in a gully head of the Penedès region (northeast Spain). Earth Surface Processes Landforms, 34: 1927-1937.

32. MGM. (2019). Çankırı Meteoroloji İstasyonu İklim Verileri. Tarım ve Orman Bakanlığı, Meteoroloji Genel Müdürlüğü, Ankara.

33. OGM. (2011-2030). Çankırı Orman İşletme Şefliği Fonksiyonel Amenajman Planı. Orman Genel Müdürlüğü (OGM), Ankara Orman Bölge Müdürlüğü, Çankırı Orman İşletme Müdürlüğü, Çankırı.

34. OGM. (2015). Türkiye Orman Varlığı. T.C. Orman ve Su İşleri Bakanlığı, Orman Genel Müdürlüğü, Ankara. 23s.

35. Oğuz, İ. (1997). Çekerek Havzası Büyük Toprak Gruplarının Bazı Özellikleri ile Su Erozyonu İlişkileri ve Havza Topraklarının Erozyon Duyarlılık Değerlendirmesi. Doktora Tezi, Gaziosmanpaşa Üniversitesi, Fen Bilimleri Enstitüsü, Toprak Anabilim Dalı, Tokat.

36. Oruç, E. (2010). Murgul Ağaçlandırma Sahasında Yalanıı Akasyanın (Robinia Pseudoacacia) Yüzeysel Akış ve Erozyonu Önlemedeki Etkisinin Araştırılması. Artvin Çoruh Üniversitesi, Fen Bilimleri Enstitüsü, Yüksek Lisans Tezi, Artvin.

37. Özkan, K. (2001). Eğirdir Gölü Havzası'nın Kuraklık Etüdü ve Tarım - Ormancılık Açısından Değerlendirmesi, Süleyman Demirel Üniversitesi, Orman Fakültesi Dergisi, Sayı:2, Isparta.

38. Sarı, M. (2000). Toprak Erozyonuna Farklı Bir Yaklaşım, Erozyonla Mücadele Tema Eğitim Semineri Notlar1, s:55-68, İstanbul.

39. Schiechtl, H.M., Görcelioğlu, E. (1971). Yamaçların tahkimi amacıyla vejetasyondan yararlanmada Avusturya'da uygulanan modern teknikler. Istanbul Üniversitesi, Orman Fakültesi Dergisi, B(XXI): 1.

40. Şahin, M., Başaran, S., Başaran, M.A., Okudan, A., Alım, E., Türkkan, M., Serttaş, A., Alagöz, Z. (2014). Burdur Yöresindeki Erozyon Alanlarının Floristik Kompozisyonu ve Erozyon Önlemede Kullanılabilecek Bitki Türlerinin Belirlenmesi. II. Ulusal Akdeniz Orman ve Çevre Sempozyumu, Isparta. 
41.Şengönül, K., Özçelik, M.S. (2014). Yarı Kurak Bölgelerde Rehabilitasyon-Toprak Koruma Çalışmalarında Kullanılabilecek Bazı Bitki Türleri, Ulusal Havza Sempozyumu, 10-12 Eylül 2014, Çankırı, s: 262-267.

42. Tuttu, G., Akkemik, Ü. (2017). Çankırı-Korubaşı tepe ve civarındaki jipsli alanların florası. Ot Sistematik Botanik Dergisi, 24(1): 45-88.

43. Yıldız, C. (2016). Yarı Kurak İklim Bölgelerinde Farklı Bakı Koşullarına Sahip Yamaçlarda Erozyon Süreçlerinin İncelenmesi (Akziyaret - Şanlıurfa). Yüksek Lisans Tezi, Harran Üniversitesi, Sosyal Bilimler Enstitüsü, Coğrafya Anabilim Dalı, Şanlıurfa.

44. Yılmaz, T. (2009). Vadilerde Fiziki Yapıya Bağlı Bitkilendirme Olanakları, Ankara Büyükesat Vadisi Örneği. Ankara Üniversitesi Çevre Bilimleri Dergisi, 1(1);0-0.

45. Zoralioğlu, T. (2006). Türkiye'de Yarı kurak Bölgelerde Yapılan Ağaçlandırma ve Erozyon Kontrolü Uygulamalarının Değerlendirilmesi. 7 - 10 Kasım 2006 Çalıştayı Bildiri Özeti, Ankara, s: 25-32. 